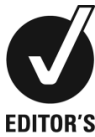

CHOICE

${ }^{1}$ North Shore-LIJ Health System, New Hyde Park, New York, USA

${ }^{2}$ Hofstra North Shore-LIJ School of Medicine, Hempstead, New York, USA

\section{Correspondence to}

Dr Mark Goldin mgoldin@nshs.edu

Accepted 6 December 2015

\title{
A hiccup in holiday plans
}

\author{
Mark Goldin, ${ }^{1}$ Zachary Hahn ${ }^{2}$
}

\section{DESCRIPTION}

A 35 -year-old man presented with 5 days of persistent hiccups and vomiting just prior to a major holiday. Twice in the past month he had visited the hospital for hiccups and had experienced no relief with chlorpromazine. This time he noted left-sided paraesthesias, previously attributed to existing C3-5 disc herniation. Physical examination revealed leftsided pronator drift, left index finger past-pointing, left upper extremity numbness and inability to ambulate due to imbalance. Routine laboratory studies were normal, although head CT and subsequent MRI revealed a C2 intramedullary mass with associated cystic structure extending from the fourth ventricle to C7 (figure 1). Over the holiday he developed blurry vision, dysphagia and night sweats. Expedited neurosurgery led to removal of a grossly orange tumour at $\mathrm{C} 2$ with decompression of cystic structures. The patient ambulated on postoperative day 1 and was discharged home with outpatient occupational therapy on postoperative day 4. Pathology was consistent with a diagnosis of haemangioblastoma (figure 2). Three-month follow-up MRI showed no recurrence, with resolution of postoperative changes.

Stimulation/irritation of any component of the hiccup reflex arc (phrenic and vagus afferents to phrenic and central midbrain nuclei, then phrenic efferents to respiratory muscles) will produce

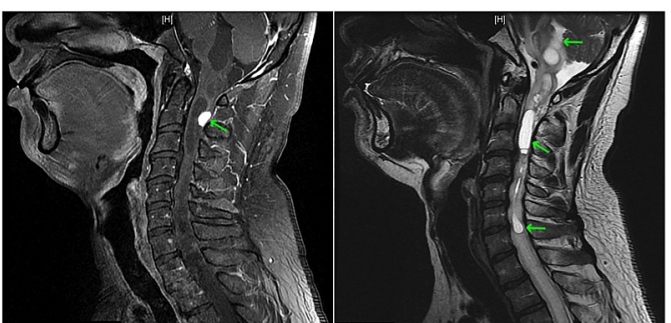

Figure 1 T1-weighted MRI, midline sagittal cut; arrow indicates solid tissue nodule of the haemangioblastoma (left). T2-weighted MRI, midline sagittal cut; arrows indicate extensive cystic structure of haemangioblastoma (right).

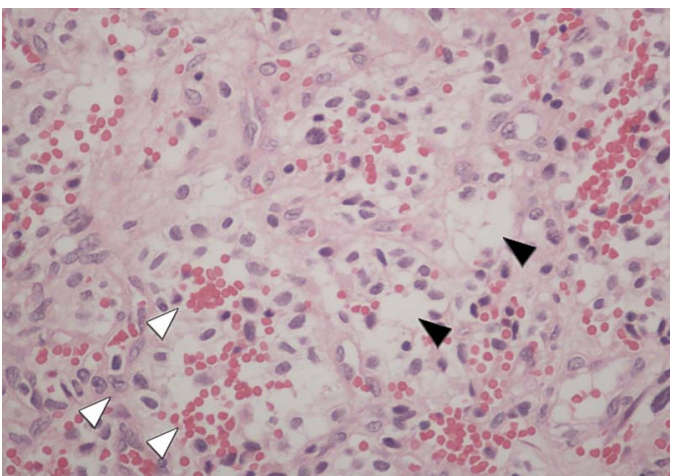

Figure 2 Pathology specimen consistent with a diagnosis of haemangioblastoma. Whit arrowheads indicate a mixture of spindle and clear cells with rich vascular network. Black arrowheads indicate clear cell features due to high cellular lipid content. Must rule out metastatic renal cell carcinoma.

hiccups, and thus a broad differential must be considered. ${ }^{1}{ }^{2}$ Metabolic derangements, nerve compression/irritation, central nervous system lesions and medications can be triggers. It is important to recognise that short bouts of hiccups are benign; however, protracted $(>48 \mathrm{~h})$ or intractable (>1 month) hiccups almost always have an underlying pathology and can be associated with significant morbidity or death. ${ }^{23}$

Contributors The authors contributed equally to the preparation of this manuscript. MG was the physician of record who managed this case, and he will serve as guarantor for the manuscript.

Competing interests None declared.

Patient consent Obtained.

Provenance and peer review Not commissioned; externally peer reviewed.

\section{REFERENCES}

1 Payne BR, Tiel RL, Payne MS, et al. Vagus nerve stimulation for chronic intractable hiccups. Case report. I Neurosurg 2005;102:935-7.

To cite: Goldin M, Hahn online: [please include Day Month Year] doi:10.1136/ bcr-2015-213288
2 Marsot-Dupuch K, Bousson V, Cabane J, et al. Intractable hiccups: the role of cerebral MR in cases without systemic cause. AJNR Am J Neuroradiol 1995; 16:2093-100.

3 Howard RS. Persistent hiccups. BMJ 1992;305:1237-8.

Copyright 2016 BMJ Publishing Group. All rights reserved. For permission to reuse any of this content visit

http://group.bmj.com/group/rights-licensing/permissions.

BMJ Case Report Fellows may re-use this article for personal use and teaching without any further permission.

Become a Fellow of BMJ Case Reports today and you can:

- Submit as many cases as you like

- Enjoy fast sympathetic peer review and rapid publication of accepted articles

- Access all the published articles

- Re-use any of the published material for personal use and teaching without further permission

For information on Institutional Fellowships contact consortiasales@bmjgroup.com

Visit casereports.bmj.com for more articles like this and to become a Fellow 